\title{
TAK1 control of cell death
}

\author{
SR Mihaly ${ }^{1}$, J Ninomiya-Tsuji ${ }^{\star, 1}$ and S Morioka ${ }^{\star, 1,3}$
}

Programmed cell death, a physiologic process for removing cells, is critically important in normal development and for elimination of damaged cells. Conversely, unattended cell death contributes to a variety of human disease pathogenesis. Thus, precise understanding of molecular mechanisms underlying control of cell death is important and relevant to public health. Recent studies emphasize that transforming growth factor- $\beta$-activated kinase 1 (TAK1) is a central regulator of cell death and is activated through a diverse set of intra- and extracellular stimuli. The physiologic importance of TAK1 and TAK1-binding proteins in cell survival and death has been demonstrated using a number of genetically engineered mice. These studies uncover an indispensable role of TAK1 and its binding proteins for maintenance of cell viability and tissue homeostasis in a variety of organs. TAK1 is known to control cell viability and inflammation through activating downstream effectors such as NF- $\kappa$ B and mitogen-activated protein kinases (MAPKs). It is also emerging that TAK1 regulates cell survival not solely through NF- $\kappa$ B but also through NF- $\kappa$ B-independent pathways such as oxidative stress and receptor-interacting protein kinase 1 (RIPK1) kinase activity-dependent pathway. Moreover, recent studies have identified TAK1's seemingly paradoxical role to induce programmed necrosis, also referred to as necroptosis. This review summarizes the consequences of TAK1 deficiency in different cell and tissue types from the perspective of cell death and also focuses on the mechanism by which TAK 1 complex inhibits or promotes programmed cell death. This review serves to synthesize our current understanding of TAK1 in cell survival and death to identify promising directions for future research and TAK1's potential relevance to human disease pathogenesis.

Cell Death and Differentiation (2014) 21, 1667-1676; doi:10.1038/cdd.2014.123; published online 22 August 2014

\section{Facts}

- TAK1 is activated by numerous exogenous and endogenous ligands, such as microbial lipopolysaccharide, IL-1, TNF $\alpha$ and TNF-related apoptosis-inducing ligand (TRAIL), and initiates cell signaling leading to the activation of NF- $\kappa$ B and MAPKs.

- Loss of TAK1 activity results in apoptosis in most tissue types.

- Prosurvival signaling, through downstream NF- $\kappa \mathrm{B}$, accounts for some but not all of the cell death observed when TAK1 is inhibited or deleted.

- Conversely, hyperactivation of TAK1 leads to receptorinteracting protein kinase 3 (RIPK3)-dependent necroptosis.

- Dysregulation of TAK1 signaling pathway in mice leads to tissue abnormalities resembling human disease pathogenesis.

\section{Open Questions}

- What are the mechanisms by which TAK1 activity is regulated in response to the rich diversity of environmental and endogenous stimuli in vivo?

- What is the precise mechanism by which TAK1 regulates apoptosis independently of NF- $\kappa \mathrm{B}$ ?

- How does TAK1 promote RIPK1/RIPK3-dependent necroptosis?

- Given TAK1's role as an inhibitor of apoptosis and inducer of necroptosis, how can inhibition of TAK1 be used therapeutically?

Programmed cell death is triggered under diverse biologic events including inflammation, tissue injury and during development. TAK1 is activated by a number of stressors such as cytokines and bacterial ligands, and then transmits

\footnotetext{
${ }^{1}$ Department of Biological Sciences, North Carolina State University, Environmental and Molecular Toxicology, Raleigh, NC 27695-7633, USA

${ }^{*}$ Corresponding authors: J Ninomiya-Tsuji or S Morioka, Department of Biological Sciences, North Carolina State University, Environmental and Molecular Toxicology, Campus Box 7633, Raleigh, NC 27695, USA. Tel: + 1919513 1586; Fax: + 1919515 7169; E-mail: Jun_Tsuji@ncsu.edu (JN-T) or Tel: +1 434982 2593; Fax: +1 434982 1071; E-mail: sm9ss@eservices.virginia.edu (SM)

${ }^{3}$ Current address: Department of Microbiology, Immunology and Cancer Biology, University of Virginia, Charlottesville, VA, USA

Abbreviations: c-FLIP, cellular FLICE-like inhibitory protein; cIAP, cellular inhibitor of apoptosis; Drp1, dynamin-related protein 1; FADD, FAS-associated via death domain; IBD, inflammatory bowel disease; IKK, I $k$ b kinase; MAPK, mitogen-activated protein kinase; MLKL, mixed lineage kinase domain-like; PGAM5, phosphoglycerate mutase family member 5; PP6, protein phosphatase 6; RIPK1, receptor-interacting protein kinase 1; RIPK3, receptor-interacting protein kinase 3; ROS, reactive oxygen species; TAB1, TAK1-binding protein 1; TAB2, TAK1-binding protein 2 ; TAK1, TGF- $\beta$-activated kinase 1 ; TGF $\beta$, transforming growth factor- $\beta$; TNFR, TNF receptor; TRADD, TNF $\alpha$ receptor type-1-associated death domain protein; TRAF, TNF $\alpha$ receptor-associated factor; TRAIL, TNF-related apoptosis-inducing ligand

Received 10.4.14; revised 09.7.14; accepted 13.7.14; Edited by G Melino; published online 22.8.14
} 
the signal-transduction pathway leading to cellular responses. TAK1 has a powerful prosurvival role in activating the $I_{k} b$ kinase (IKK)-NF- $\kappa$ B pathway, which has a number of target genes, many of which block apoptosis, promote cell proliferation and stimulate inflammatory responses. ${ }^{1-3}$ Loss of TAK1 sensitizes cells to death through many of the myriad pathways known to activate TAK1, including TNF $\alpha$. However, accumulating results suggest that TAK1 is essential for cell survival, above and beyond its role in NF- $\kappa \mathrm{B}$ activation through pathways that are discussed in this review. Furthermore, despite TAK1's prosurvival function, TAK1 has also been found to participate actively in the RIPK1- and RIPK3-mediated necroptosis pathway under some circumstances. The story of TAK1 in maintaining and disrupting life leads to the conceptual synthesis of TAK1 as a regulator of cell fate. This review discusses the role of TAK1 signaling in cell death by incorporating TAK1's multiple paths to cell survival and cell death. Control of survival and cell death may allow us to target specific cells, such as tumor cells, for particular types of cell death.

\section{TAK1 Activation and Downstream Pathways}

The kinase TAK1 was first identified as a mitogen-activated protein kinase kinase kinase (MAP3K) and found to be activated by TGF $\beta$ and bone morphologic protein. ${ }^{4}$ Since this original finding, TAK1 also has been shown to be activated by a number of signaling molecules including cytokines such as TNF $\alpha$ and IL-1; ligands that interact with Toll-like receptors, $\mathrm{B}$-cell receptor and T-cell receptor; and the lipotoxic molecule, ceramide. $^{5-13}$ Other endogenous death ligands of the TNF family, including TRAIL, also induce TAK1 activation. ${ }^{14,15}$
Exogenous stressors and environmental changes such as osmotic stress, UV irradiation, ischemia and nutrient withdrawal activate TAK1. ${ }^{13,14,16,17}$ Among these stimuli, the mechanism of TAK1 activation and its role in the TNF $\alpha$ signaling pathway has been extensively studied. Upon TNF $\alpha$ stimulation, adaptor molecules including TNF $\alpha$ receptor type1 -associated death domain protein (TRADD), TNF $\alpha$ receptorassociated factor 2 and 5 (TRAF2 and TRAF5), cellular inhibitor of apoptosis 1 and 2 (clAP1/2) and RIPK1 are recruited to the receptor complex (TNF receptor 1 (TNFR1) Complex I) (Figure 1), in which RIPK1 acquires a K63-linked or linear polyubiquitin chain by E3 ligases, TRAF2/5 clAP1/2 or linear ubiquitin chain assembly complex containing two E3 ligases HOIL-1 and HOIP. ${ }^{18-22}$ TAK1 is recruited and activated through TAK1-binding protein 2 (TAB2) binding to the RIPK1 polyubiquitin chain. ${ }^{23,24}$ Upon binding the polyubiquitin chain, TAK1 phosphorylates and activates the IKK complex composed of IKK $\alpha, \mathrm{IKK} \beta$ and NEMO (also called $\mathrm{IKK} \gamma$ ), which leads to phosphorylation and degradation of $\mathrm{I}_{\kappa} \mathrm{B}$ resulting in activation of NF- $\kappa \mathrm{B}$ (Figure 1). Activated TAK1 also phosphorylates and activates MAPKKs leading to activation of MAPKs such as ERK, p38 and JNK (Figure 1). ${ }^{6,25} \mathrm{NF}-\kappa \mathrm{B}$ and MAPKs induce downstream expression of inflammatory cytokines and antiapoptotic proteins such as cellular FLICE-like inhibitory protein (c-FLIP) and clAPs. ${ }^{26,27}$ Drawing a link between TAK1 signaling and metabolism, studies have found that starvation and TRAIL induce autophagy in which TAK1 is actively involved by activating AMP-activated protein kinase and IKKs. ${ }^{14,17,28,29}$ In summary, TAK1 responds to exogenous stress conditions through a variety of mechanisms including TNF $\alpha$ family

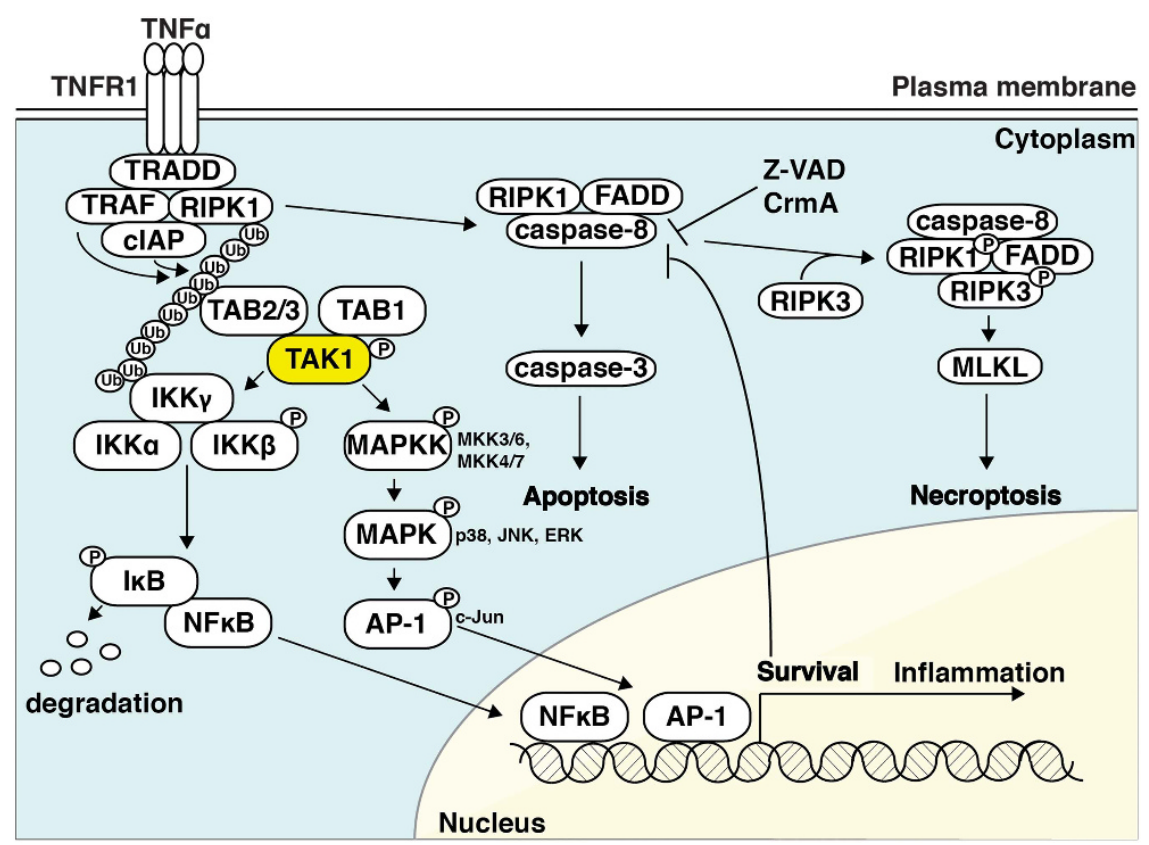

Figure 1 TNF $\alpha$ induces cell survival, apoptosis and necroptosis. Upon TNF $\alpha$ stimulation, TNFR1 forms Complex I, in which RIPK1 acquires a polyubiquitin chain. ${ }^{18-21}$ TAK1 binds to the polyubiquitin chain though TAB2, and activates the IKK complex, leading to the activation of NF- $\kappa$ B. TAK1 also activates MAPK cascades. ${ }^{6,25} \mathrm{NF}-\kappa \mathrm{B}$ and MAPKs induce expression of inflammatory cytokines and antiapoptotic proteins. ${ }^{26,27}$ After Complex I formation, under some circumstances, the complex dissociates from TNFR1, leading to the formation of cytosolic protein complex known as Complex lla composed of TRADD, FADD, RIPK1 and caspase-8 ${ }^{43}$ Caspase-8 activation initiates a caspase cascade, which leads to apoptotic cell death. ${ }^{44}$ If caspase-8 is inhibited, Complex Ilb which include FADD, RIPK1 and RIPK3 is formed. ${ }^{45}$ RIPK1-RIPK3 executes necroptosis through downstream molecule such as $\mathrm{MLKL}^{46-48}$ 
receptors, and activates cellular processes to mitigate stress conditions through intracellular signaling pathways including, but not limited to, IKK-NF- $\kappa$ B and MAPK pathways (Figure 1).

\section{The Roles of TAK1-Binding Proteins in TAK1 Activation}

TAK1 forms complexes with its binding proteins TAB1, TAB2 and $\mathrm{TAB} 3 .^{30-32} \mathrm{TAB} 2$ and $\mathrm{TAB} 3$ are close homologs, whereas $T A B 1$ is structurally unrelated to $T A B 2$ or TAB3. $\mathrm{TAB} 1$ and $\mathrm{TAB} 2 / \mathrm{TAB} 3$ bind to the $\mathrm{N}$-terminal kinase domain and the C-terminal region of TAK1, respectively. TAB1 mediates oligomerization, autophosphorylation and activation of TAK1. ${ }^{16,33,34}$ TAB1 is essential for TAK1 activation in response to osmotic stress but dispensable for cytokinemediated TAK1 activation. ${ }^{16} \mathrm{O}$-linked glycosylation of TAB1 on S395 is implicated in activation of TAK1 activation in response to osmotic stress. ${ }^{35}$ In contrast, TAB2 and its analogous protein TAB3 have been shown to have an important role in activation of TAK1 in cytokine signaling. TAB2 and TAB3 each have Np14 zinc-finger domain, which is necessary for recruitment of TAK1 to the RIPK1 polyubiquitin chain in the TNF $\alpha$ signaling pathway (Figure 1). ${ }^{18,24}$ Consistently, inhibition of TAB2 reduces TAK1 activity in several tissues and cell types. ${ }^{32,36,37}$ However, Broglie et al. ${ }^{38}$ described that loss of Tab2 in dermal fibroblasts rather prolonged and increased the activation of TAK1 following TNF $\alpha$ stimulation. TAK1 is normally transiently activated by TNF $\alpha$ and deactivated by protein phosphatase 6 (PP6) ${ }^{39}$ and protein phosphatase $2 A{ }^{40}$ TAB2 tethers the interaction between TAK1 and PP6 on the RIPK1 polyubiquitin chain in the TNF $\alpha$ signaling pathway, which may explain how TAB2 deficiency could lead to sustained activation of TAK1. In this context, activation of TAK1 may be compensated for by TAB3. While structurally very different, TAB1 and TAB2, at least in the epidermis, intestinal epithelium and differentiated macrophages have been shown to function redundantly to activate TAK1. ${ }^{41,42}$ As double deletion of Tab1 and Tab2 almost completely ablates TAK1 activity and phenocopies Tak1 deletion in the epidermis and intestinal epithelium, TAB3 does not appear to have a dominant role in TAK1 activation in these tissues. Further elucidation of the roles of these individual binding proteins requires more study, but it must be stressed that activation of TAK1 is regulated by TAB1, $\mathrm{TAB} 2$ and $\mathrm{TAB} 3$ in vivo, and their respective contributions are complex and depend upon tissue type and cellular context.

\section{TAK1 Inhibits Apoptosis}

When TAK1 is absent, cells are sensitive to cell death in response to several stressors. Among them, TAK1-regulated TNF $\alpha$-induced cell death is well characterized. After TNF $\alpha$ receptor complex (Complex I) formation, under some circumstances, the TNF $\alpha$-bound receptor complex dissociates from TNFR1, leading to molecular reorganization and the formation of a cytosolic death-inducing signaling complex including TRADD, FAS-associated protein with a death domain (FADD), RIPK1 and caspase-8, known as Complex Ila (Figure 1). ${ }^{43}$ In this complex, caspase- 8 is dimerized, selfcleaved and activated to further activate downstream executioner caspases such as caspase-3, which leads to apoptotic cell death. ${ }^{44}$ Moreover, if caspase- 8 is perturbed by gene deletion or inhibited by a viral protein CrmA or by pharmacologic inhibitors, TNF $\alpha$ induces another shift of protein complexes toward Complex IIb that include FADD, RIPK1 and RIPK3 (Figure 1). ${ }^{45}$ RIPK1-RIPK3 executes programmed necrosis, which is often called necroptosis, to induce an alternative cell death pathway when apoptosis fails. ${ }^{46-48}$ Inhibition of TAK 1 is usually followed by caspase- 8 and -3 activation in response to $\mathrm{TNF} \alpha$, which suggests that TAK1 inhibits caspase activation cascade to block apoptotic cell death. ${ }^{49}$ Thus, TAK1 is likely to blunt the formation or activation of Complex Ila. Recent studies revealed two major mechanisms through which TAK1 inhibits caspase activation (Figure 2).

TAK1-NF- $\kappa B$ pathway: TAK1 is a well-documented upstream kinase of NF- $\kappa \mathrm{B}^{3,6,7} \mathrm{NF}-\kappa \mathrm{B}$ transcriptionally upregulates antiapoptotic protein such as c-FLIP and IAP family proteins (Figure 1). The IAP family includes cIAP1, cIAP2 and XIAP, which can inhibit caspase activation. ${ }^{50}$ c-FLIP is structurally similar to caspases-8 but does not possess protease activity and forms a heterodimer with caspase-8, which competitively inhibits formation of highly active caspase-8 homodimer. ${ }^{51,52}$ We note here that c-FLIPcaspase- 8 heterodimer still possesses limited proteolytic activity, ${ }^{53,54}$ which is important for cross-talk between apoptosis and necroptosis, as discussed later. Thus, it is feasible that TAK1 inhibits caspase activation through activation of $\mathrm{NF}-\kappa \mathrm{B}$. However, it also suggests that an $\mathrm{NF}-\kappa \mathrm{B}$-independent pathway is responsible for inhibition of apoptosis. In mouse models, Tak1 deletion causes more extensive cell death and tissue damage than ablation of $\mathrm{NF}-\kappa \mathrm{B}$ by deletion of IKK $\beta$ or NEMO/IKK $\gamma$ (see Table 1). Intestinal epithelial-specific Tak1 gene deletion causes

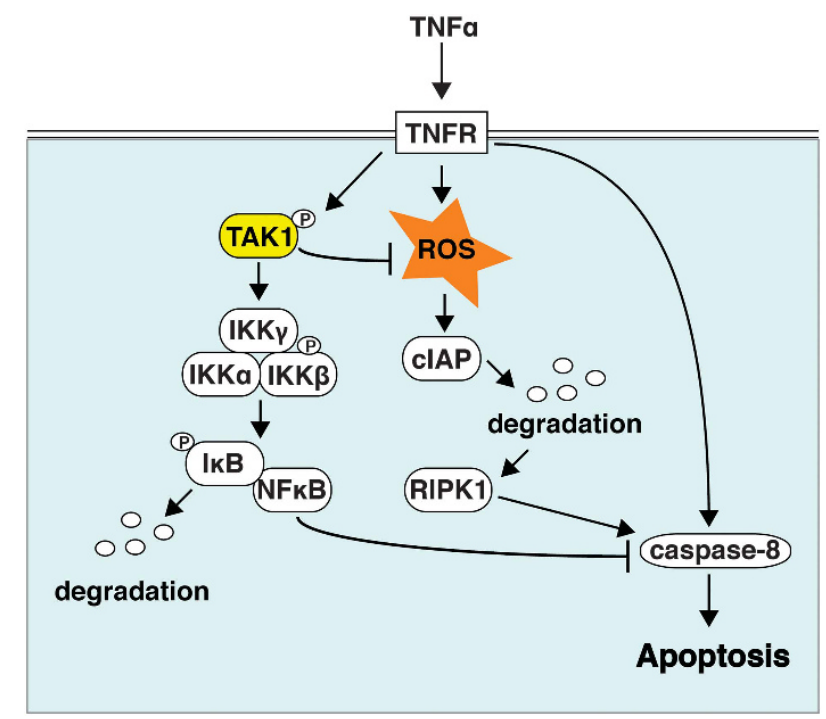

Figure 2 TAK1 protects cells from TNF $\alpha$-induced apoptosis through two distinct pathways. TAK1 is an upstream kinase of NF- $\kappa B$. ${ }^{6} \mathrm{NF}-\kappa \mathrm{B}$ transcriptionally upregulates antiapoptotic protein such as C-FLIP and IAP family proteins that inhibit caspase activation. ${ }^{26,27}$ In addition, TAK1 prevents TNF $\alpha$-induced accumulation of ROS. ROS potentially cause depletion of cIAP proteins, ${ }^{15}$ resulting in deubiquitination of RIPK1. This form of RIPK1 can activate caspase-8 in a kinase-dependent manner. ${ }^{61}$ Thus, TAK1-NF- $\kappa$ B pathway and TAK1-dependent antioxidant pathway coordinately inhibit caspase activation and apoptotic cell death 
TNF $\alpha$-dependent tissue disruption from embryonic day 18.5, whereas ablation of IKK $\beta$ or NEMO/IKK $\gamma$ does not cause significant cell death at early postnatal days. ${ }^{55,56}$ Hepatocyte-specific deletion of TAK 1 triggers TNF $\alpha$-dependent liver injury and hepatocellular carcinoma within 6 weeks of age, whereas loss of NF- $\kappa \mathrm{B}$ activation by NEMO deletion causes much milder liver injury around 20 weeks of age. ${ }^{57}$ Furthermore, it appears that NF- $\kappa \mathrm{B}$ activity is not always regulated by TAK1 in some tissues in vivo. For example, Tak1 deletion in blood vessels leads to TNF $\alpha$-induced endothelial cell death without altering NF- $\kappa$ B activity. ${ }^{37}$ Thus, impairment of NF- $\kappa \mathrm{B}$ may not be the sole mechanism for cell death in Tak1-deficient cells (Figure 2).

TAK1-ROS-cIAP pathway: TNF $\alpha$-induced caspase activation and subsequent cell death in Tak1-deficient cells is effectively blocked by gene deletion of Ripk1 or necrostatin-1, a pharmacologic inhibitor of RIPK1 kinase activity. ${ }^{49,58,59}$ Thus, Tak1 deficiency engages RIPK1-dependent apoptosis. However, previous studies demonstrate that extrinsic apoptosis induced by TNF family ligands is usually RIPK1independent, ${ }^{60}$ and kinase activity of RIPK1 is not required for caspase activation. ${ }^{61}$ Only when clAP is depleted by synthetic IAP antagonists (smac mimetics) or by genotoxic stress does TNF $\alpha$ or genotoxic stress induces RIPK1 kinase activity-dependent caspase-8 activation. ${ }^{62,63}$ clAPs are responsible for K63-linked polyubiquitination of RIPK1, ${ }^{64}$ which inhibits formation of Complex Ila (Figure 1). ${ }^{62}$ Interestingly, inhibition of TAK1 decreases the protein amount of clAPs following stimulation of TNF $\alpha .{ }^{15}$ Thus, TAK1 is important for maintenance of clAP protein amount, which blocks Complex Ila activation. By what mechanism is clAP reduced in Tak1-deficient cells? It has been demonstrated that Tak1 deficiency accumulates reactive oxygen species (ROS) in response to $\mathrm{TNF} \alpha$ stimulation, and ROS scavengers rescue cell death in vitro and in vivo. ${ }^{15,65,66}$ One possible mechanism is that stress-induced ROS lead to degradation of clAPs. Indeed, TNF $\alpha$-induced loss of clAPs in Tak1-deficient cells is restored by treatment with ROS scavenger, butylated hydroxyanisole. ${ }^{15}$ Because depletion of NF- $\kappa \mathrm{B}$ only marginally increases ROS under the same experimental condition as Tak1 deletion, ${ }^{66}$ TAK1-ROS-clAP pathway seems to act independently of TAK1-NF- $\kappa$ B pathway. Future studies need to identify the molecular pathways though which TAK1 modulates cellular redox status. In summary, not only activation of TAK1-IKK-NF- $\kappa$ B pathway but also TAK1 regulation of cellular redox system are the keys to inhibit apoptosis (Figure 2). Future efforts should focus on the unidentified mechanism of TAK1-dependent alteration of cellular redox status.

\section{TAK1 as a Necroptosis Inducer}

Is TAK1 only involved in caspase-dependent cell death? Another interesting topic is the relationship between TAK1 and a different form of programmed cell death, necroptosis. When apoptosis is blocked by inhibition of caspase-8, RIPK1 and RIPK3 form Complex Ilb, and they execute necroptosis, a regulated form of necrosis (Figure 1). RIPK3 phosphorylates mixed lineage kinase domain-like (MLKL), which induces oligomerization of $\mathrm{MLKL}$ resulting in plasma membrane rupture. ${ }^{67-69}$ In human cells, it has been proposed that MLKL modulates phosphoglycerate mutase family member 5 (PGAM5) and dynamin-related protein 1 (Drp1), in which Drp1 mediates mitochondrial fragmentation, which is necessary for metabolic inactivation and induction of necroptosis. ${ }^{69,70}$ However, recent evidence suggests that PGAM5 and Drp1 may not be required for execution of necroptosis in murine cells. ${ }^{71,72}$ Nonetheless, catalytically active RIPK1 and RIPK3 are important for stable RIPK1-RIPK3 complex formation and subsequent execution of necroptotic cell death. ${ }^{73-75}$ In this context, necrostatin-1 is widely used for improving tissue damage mediated by necroptosis induction. ${ }^{61}$ A surprising finding regarding the regulation of RIPK1 and RIPK3 phosphorylation came from the analysis of Tab2deficient fibroblasts, which exhibit sustained activation of TAK1 following TNF $\alpha$ stimulation. ${ }^{38}$ Despite the presence of TAK1 activation, Tab2-deficient fibroblasts are killed by TNF $\alpha$ challenge. ${ }^{49}$ Interestingly, while Tak1 deficiency induces caspase activation leading to apoptosis upon TNF $\alpha$ stimulation, Tab2 deficiency shows almost no caspase activation and results in cell death having typical necrotic features such as plasma membrane rupture. ${ }^{49}$ Furthermore, TNF $\alpha$-induced cell death in Tab2-deficient fibroblasts is almost completely rescued by Ripk3 deletion, whereas Ripk3 deletion has no effect on Tak1-deficient fibroblasts. Thus, Tab2 deletion causes necroptosis following TNF $\alpha$ stimulation. Two lines of evidence show that sustained TAK1 activation causes RIPK3dependent necroptosis. One is that enforced activation of TAK1 through overexpression induces RIPK3 phosphorylation and necroptosis. The other is that additional deletion of Tak1 in Tab2-deficient fibroblasts solely induces caspasedependent apoptosis following TNF $\alpha$ stimulation. ${ }^{49}$ These results collectively reveal an unexpected role of TAK1 in cell death pathways, as an inducer of necroptosis (Figure 3). Furthermore, it has been shown that TAK1 activates RIPK3, reciprocally RIPK3 activates TAK1, and these activations are facilitated by RIPK1, which mediates TAK1-RIPK1-RIPK3 binding. ${ }^{49}$ Thus, TAK1-RIPK1-RIPK3 is activated by a positive feedforward mechanism (Figure 3$).{ }^{49}$ How is TAKRIPK1-RIPK3 assembled? Deubiquitination of RIPK1 is known to be the critical process for assembly of the necroptotic complex. ${ }^{62,76}$ Conversely, stabilization of RIPK1 polyubiquitin chain prevents necroptosis. ${ }^{76}$ As discussed earlier, TAB2 is a polyubiquitin chain-binding protein and directly binds to TAK1. Hence, TAB2 tethers the binding between TAK1 and polyubiquitin chain of RIPK1 (Figure 1). Thus, the absence of TAB2 prevents TAK1 binding to the RIPK1 polyubiquitin chain, which could lead to an alternative type of binding between TAK1 and RIPK1, resulting in activation of TAK1-RIPK1-RIPK3 assembly (Figure 3). Alternatively, under pathologic conditions, viral inhibition of caspase promotes deubiquitination of RIPK1 and releases TAK1 from the polyubiquitin chain, which may result in the assembly of TAK1-RIPK1-RIPK3 (Figure 3). These possibilities should be investigated in the future studies. Although it is clear that TAK1 promotes RIPK3 activity, the importance of TAK1 in necroptosis needs to be carefully considered. Our results suggest that Tak1 deletion induces caspase-8 activation but, even if caspase-8 is inhibited, Tak1deficient cells still undergo cell death following $\mathrm{TNF} \alpha$ 

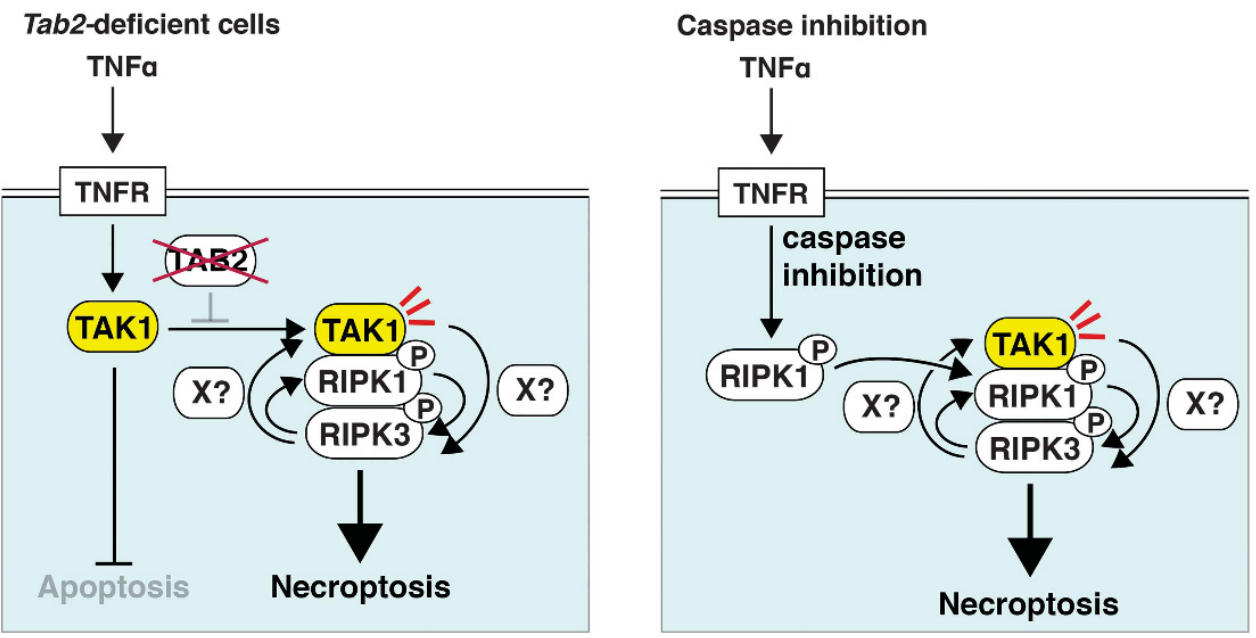

Figure 3 TAK1 enhances necroptosis. RIPK3 is activated through two pathways: (1) deletion of Tab2 leads to TAK1 activation in a sustained manner following TNF $\alpha$ stimulation. ${ }^{38}$ Sustained activation of TAK1 binds to and activates RIPK1 and RIPK3. TAK1 can increase phosphorylation and activation of RIPK3, and conversely, RIPK3 can increase phosphorylation and activation of TAK $1{ }^{49}$ However, it is still not clear whether TAK1 and RIPK3 directly phosphorylate each other; (2) when caspase-8 is blocked, RIPK1 and RIPK3 form Complex Ilb to induce necroptosis. Phosphorylation of RIPK1 and RIPK3 are important for stable RIPK1-RIPK3 complex formation, ${ }^{73-75}$ where TAK1 is also activated and facilitates RIPK3 activation, resulting in the activation of a feedforward loop between TAK1-RIPK1-RIPK3

stimulation. ${ }^{49}$ In line with this, combined inhibition of caspase and RIPK3 rescues TNF $\alpha$-induced cell death in Tak1-deficient cells. ${ }^{58,77-79}$ These results suggest that, although the default pathway of cell death in Tak1-deficient cells is apoptosis, Tak1 deficiency engages an alternative RIPK1-RIPK3 necroptosis pathway if the default pathway is blocked. Interestingly, even though RIPK1 was believed to be an essential mediator of RIPK3 activation, necroptosis can still be engaged with Ripk1 deletion. $^{80,81}$ Thus, necroptosis may be mediated through not only TAK1-RIPK1-RIPK3 complex but also through alternative complexes lacking either TAK1 or RIPK1. In summary, despite the fact that Tak1 deletion leads to hypersensitivity to TNF $\alpha$-induced cell death (apoptosis), activation of TAK1 is also associated with $\mathrm{TNF} \alpha$-induced cell death (necroptosis). We will discuss later why TAK1 has such seemingly paradoxical roles in cell death.

\section{Pathology of Tak1 Deficiency in a Variety of Tissue in Mouse Models}

Deficient TAK1 signaling in mice disrupts tissue homeostasis and provokes damage to tissues that often resembles human disease pathologies, as listed in Table 1. Epithelial cellspecific deletion of Tak1 in the epidermis or intestinal epithelium causes caspase activation and cell death leading to severe inflammation, which resembles psoriasis in the case of epidermal Tak1 deletion, and inflammatory bowel disease (IBD) in intestinal epithelium Tak1 deletion. ${ }^{55,65,66,82}$ Endothelium-specific deletion of Tak1 causes endothelial cell death and blood vessel regression around E10-11, which results in embryonic lethality. ${ }^{37}$ Hepatocyte-specific deletion of Tak1 also causes cell death and liver injury. ${ }^{57,83}$ However, unlike epithelial and endothelial tissues, Tak1 deficiency in hepatocytes does not cause profound tissue damage and is not associated with immediate animal mortality. Instead, Tak1deficient hepatocyte death induces inflammation and promotes compensatory proliferation, which eventually leads to hepatocellular carcinoma within 6 weeks. ${ }^{57,83}$
Hematopoietic-specific Tak1 deletion depletes hematopoietic progenitor cells, T cells and macrophages. ${ }^{10-12,58,84-87}$ Deletion of TNF receptor 1 (Tnfr1) largely rescues these injuries and animal mortalities, ${ }^{37,55,57,82-85}$ demonstrating that TNF $\alpha$ is the major killer of Tak1-deficient cells in these tissues. However, some Tak1-deficient tissue injuries are still observed in Tnfr1null background. ${ }^{37,65,84,85}$ Thus, Tak1 deficiency appears to also induce $\mathrm{TNF} \alpha$-independent cell death in vivo through mechanisms likely to be mediated by other TAK1 stimuli, including bacterial moieties and nutrient and genotoxic stress. Nonetheless, these tissue injuries are associated with caspase activation and are not rescued by Ripk3 deletion, indicating that they are primarily apoptosis. ${ }^{37,49,55,57,82-85,88}$ We note here that the role of TAK1 in vivo may not be limited to prevention of cell death. For example, Tak1-deficient neutrophils hyperproliferate rather than dying spontaneously, leading to splenomegaly and myelomonocytic leukemia. ${ }^{87,89}$ Although TAK1 is known as an activator of NF- $\kappa \mathrm{B}$ and p38 MAPK, Tak1 deletion in neutrophils increases activity of these downstream factors, which warrants further mechanistic analysis. Finally, we recently show that Tab2 deletion exaggerates wound-induced cell death and delays wound healing in vivo. ${ }^{49}$ As Tab2 deletion potentially results in hyperactivation of TAK1 in dermal fibroblasts as discussed earlier and the delay in wound healing is restored by blocking necroptosis (Ripk3 deletion), TAK1 is likely to be actively involved in induction of necroptosis at least in the wound response. TAK1 may also be potentially hyperactivated when caspase is exogenously inhibited by viral infection or under yet unidentified conditions, which could be associated with pathologic necroptotic conditions such as ischemic tissue injuries and systemic inflammation. ${ }^{90,91}$

\section{Functional Interaction of TAK1 and Other Cell Death Molecules In Vivo}

The physiologic importance of other cell death molecules has also been extensively studied for the past several years, and 
Table 1 Phenotypes of cell death gene deletion in mouse models

\begin{tabular}{|c|c|c|}
\hline Gene & $\begin{array}{l}\text { Phenotype of germline } \\
\text { deletion }\end{array}$ & Summary of phenotypes in tissue-specific gene deletion \\
\hline$I k k \beta$ & Lethal E12-13 $106-108$ & $\begin{array}{l}\text { (Epidermis) Increased cell death-> } \text { Lethal P8-9 }^{109} \\
\text { (Intestinal epithelium) Normal } \\
\text { (Liver) Normal }^{111} \\
\text { (Hematopoietic system) T-cell death } \\
\text { (Myeloid) Normal }^{113}\end{array}$ \\
\hline$N E M O(I k k \gamma)$ & Lethal E12-13 114,115 & $\begin{array}{l}\text { (Epidermis) Increased cell death- }>\text { Lethal P7-10 } 116 \\
\text { (Intestinal epithelium) Inflammation }->\text { Ccolitis after } 3 \text { weeks of age }{ }^{56} \\
\text { (Endothelium/blood vessel) Normal }{ }^{117} \\
\text { (Liver) Hepatocellular carcinoma around } 9-12 \text { months of age }{ }^{118}\end{array}$ \\
\hline Tak1 & Lethal E10-11 $8,25,119$ & 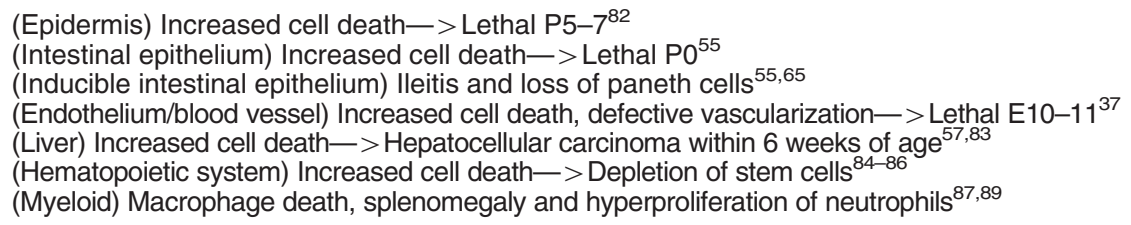 \\
\hline Tab1 & Lethal E15-16 120,121 & $\begin{array}{l}\text { (Epidermis, intestinal epithelium) Normal but double deletion of Tab1 and Tab2 phenocopies } \\
\text { Tak1 deletion }{ }^{41} \\
\text { (Endothelium/blood vessel) Normal }^{37} \\
\text { (Liver) Normal }{ }^{36} \\
\text { (Macrophage) Cell death upon treatment with lipopolysaccharide }{ }^{42}\end{array}$ \\
\hline Tab2 & Lethal E12-13 122 & $\begin{array}{l}\text { (Epidermis, intestinal epithelium) Normal but double deletion of Tab1 and Tab2 phenocopies } \\
\text { Tak1 deletion }{ }^{41} \\
\text { (Endothelium/blood vessel) Vessel dilation-> Lethal E12-13 } 37 \\
\text { (Liver) Normal but mild fibrosis in aged mice }{ }^{36} \\
\text { (Macrophage) Cell death upon treatment with lipopolysaccharide }{ }^{42}\end{array}$ \\
\hline Tab3 & Normal $^{123}$ & \\
\hline Caspase 8 & Lethal E10-11 124 & $\begin{array}{l}\text { (Epidermis) Increased cell death-> Lethal by } \mathrm{P} 7^{92} \\
\text { (Inducible intestinal epithelium) lleitis and loss of paneth cells, which can be restored by Ripk3 } \\
\text { deletion }{ }^{93} \\
\text { (Liver) Normal }^{125} \\
\text { (Endothelium/blood vessel) Defective vascularization }{ }^{125}->\text { Lethal }^{2} 10-12^{125}\end{array}$ \\
\hline Fadd & Lethal E10-12 126,127 & (Intestinal epithelium) Ileitis that can be restored by Ripk3 deletion ${ }^{95}$ \\
\hline c-Flip & $\begin{array}{l}\text { Lethal E10-11 } \\
\text { Defective vascularization }\end{array}$ & 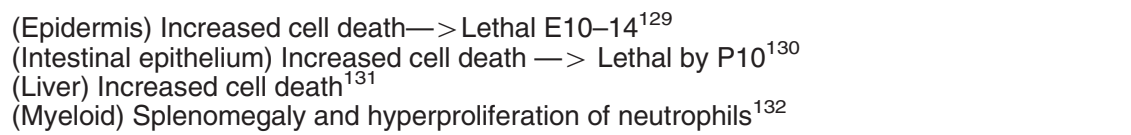 \\
\hline
\end{tabular}

$\begin{array}{ll}\text { Ripk1 } & \text { Lethal E18-P0 } \\ & \text { Systemic inflammation, TNF } \alpha \text {-induced apoptosis and RIPK3-induced necroptosis are the causes of mouse mortality }{ }^{80,81} \\ \text { Ripk3 } & \text { Normal }^{105}\end{array}$

\section{Knock-in gene Phenotype of germline knock-in}

Ripk1 kinase-dead Normal ${ }^{97}$

Ripk3 kinase-dead Lethal E10-11

Defective vascularization $^{97}$

research has revealed that programmed cell death deficiencies lead to disparate pathologies (Table 1). Interestingly, there are many phenotypic similarities among mouse models harboring deletion of Tak1 and other cell death genes (Table 1), suggesting in vivo functional interactions among them. The most surprising similarity is shared by mice having gene deletion of Tak1 or caspase-8. For example, either Tak1 or caspase-8 deletion in the epidermis results in psoriasis-like skin inflammation resulting in animal mortality around postnatal days 5-8 (P5-8). ${ }^{82,92}$ Inducible deletion of Tak1 or caspase-8 in the intestinal epithelium causes IBD-like intestinal inflammation, which is associated with loss of a specific cell type known as paneth cells. ${ }^{55,93}$ Similarly, epidermal- and intestinal epithelium-specific deletion of Fadd, which abrogates caspase- 8 activation, causes inflammatory skin disease and IBD-like ileitis. ${ }^{94,95}$ Although either Tak1 or Fadd/caspase- 8 deletion causes cell death, the types of cell death are different. Tak1 deletion is associated with the activation of downstream caspase- $3,{ }^{55,82}$ whereas deletion of caspase- 8 induces necroptosis in vivo, which is rescued by deletion of Ripk3. ${ }^{54,95,96}$ Why are the timing and features of tissue injury so similar in mice having deletion of Tak1 or 


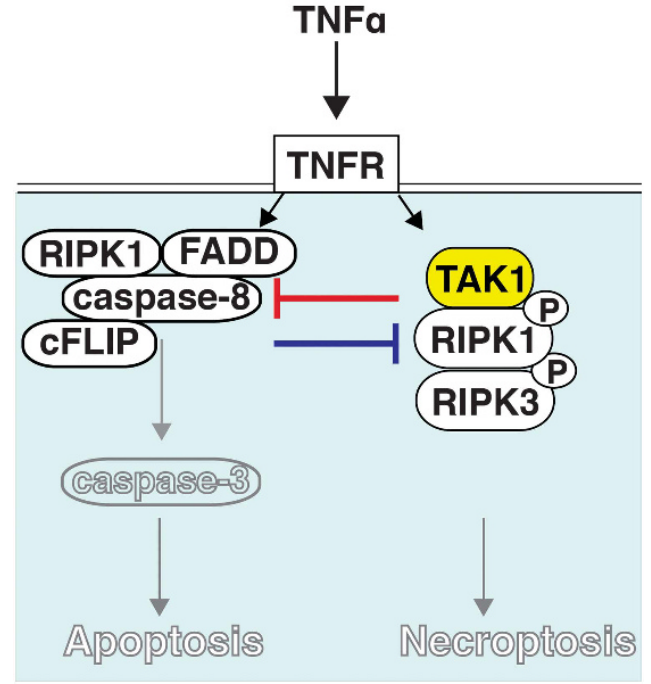

Figure 4 TAK1 and caspase are reciprocally regulated. Recent evidence indicates that apoptosis and necroptosis are reciprocally regulated. Inhibition of caspase or deletion of c-FLIP induces necroptosis, whereas inhibition of TAK1 or RIPK3 induces apoptosis. We propose that the balance between apoptotic and necroptotic signals prevents cell death under normal conditions, and any event that causes imbalance between these reciprocal inhibitions, such as treatment with a caspase inhibitor, leads to cell death

caspase-8? There is a well-studied inhibitory regulation from apoptosis to necroptosis (Figure 4, blue inhibition arrow). Thus, inhibition of caspase-8 activates necroptosis. The recent finding of TAK1 as a mediator of necroptosis raises the interesting possibility that there is an additional inhibitory regulation from necroptosis to apoptosis (Figure 4, red inhibition arrow). Two lines of evidence support the idea that necroptosis inhibits apoptosis: (1) inhibition of RIPK3 by expressing a kinase-dead version of RIPK3 is reported to cause apoptotic cell death in vivo, which results in blood vessel abnormalities similar to endothelial-specific deletion of Tak $1 ; 37,97$ (2) deletion of Ripk1 primarily induces apoptotic cell death and tissue injury in vivo, although necroptosis is also induced. ${ }^{80,81}$ Thus, inhibition and/or deletion of any part of the necroptotic protein kinase cascade (TAK1, RIPK1 or RIPK3) activates apoptotic cell death in vivo. Based on these, we propose that apoptosis and necroptosis are reciprocally regulated (Figure 4). Because of this reciprocal regulation, if one cell death pathway is inhibited, the other cell death is spontaneously activated, resulting in similar tissue injuries with the same timing in Tak1 or caspase-8-deficient tissues. What are the molecular mechanisms for these inhibitory reciprocal regulations? Caspase-8-c-FLIP heterodimer is known to be the key modulator for inhibition of necroptosis. ${ }^{51,54,98,99}$ Deletion of $c$-Flip causes embryonic lethality with blood vessel abnormality similar to deletion of caspase-8 or of Tak1 (Table 1). ${ }^{98}$ Thus far, two mechanisms for caspase-cFLIP inhibition of necroptosis are proposed: one is that caspase-8-c-FLIP cleaves and degrades RIPK1 and RIPK3; ${ }^{100,101}$ and the other is that caspase- 8 cleaves and degrades a deubiquitinase CYLD, resulting in stabilization of the polyubiquitin chain of RIPK1, which prevents RIPK3 activation. ${ }^{76}$ In contrast to caspase-8-c-FLIP regulation of necroptosis, the regulation of apoptosis by necroptosis signaling proteins is just beginning to be investigated. It has thus far been clear that the necroptosis-mediated inhibition of apoptosis possesses unique and complex features. Only manipulation of TAK1 induces predictable outcomes, in which both deletion of Tak1 gene and inhibition of TAK1 by a selective inhibitor, 5Z-7-oxozeaenol, ${ }^{102}$ activates apoptotic cell death. ${ }^{103,104}$ In contrast, it is very puzzling that inhibition and gene deletion of RIPK1 and RIPK3 result in different phenotypes. Inhibition of RIPK3 kinase activity activates caspases and tissue injury, ${ }^{97}$ whereas deletion of Ripk3 does not cause any abnormality. ${ }^{105}$ Conversely, inhibition of RIPK1 by knocking-in a kinase-dead version of RIPK1 or necrostatin1 treatment does not cause any tissue injury, ${ }^{47,97}$ whereas deletion of Ripk 1 causes cell death and systemic inflammation in vivo. ${ }^{80,81}$ It should be of immediate interest to elucidate the molecular mechanism of how TAK1, RIPK1 and RIPK3 interplay to inhibit apoptosis pathways.

\section{Conclusions}

It is clear that TAK1 is a key molecular component in the determination of cell fate. Historically, the role of TAK1 has been considered prosurvival, first characterized by antiapoptotic proteins downstream of $\mathrm{NF}-\kappa \mathrm{B}$ and cell growth and proliferation downstream of MAPK pathways. We now know that TAK1 engages multiple downstream cell death pathways in response to a rich diversity of environmental and endogenous stimuli. As an inhibitor of caspase activation, TAK1 prevents TNF $\alpha$-mediated apoptotic cell death through modulation of the RIPK1-FADD-caspase-8 pathway. An NF$\kappa \mathrm{B}$-independent cell survival pathway downstream of TAK1 has just begun to be explored, with interesting possibilities involving ROS and clAPs. However, when caspase- 8 is blocked or TAK1 activation is sustained, TAK1 acts as a cell death inducer through necroptosis activation. Similarly, the mechanism by which TAK1 promotes RIPK1/RIPK3-dependent necroptosis warrants further study. Enforcing cell death pathways can be used therapeutically to kill undesired cells such as tumor cells. Inhibition of TAK1 induces stressdependent apoptosis. Furthermore, although some tumor cells are known to gain antiapoptotic functions, inhibition of TAK1 alone is effective as inhibition of both TAK1 and caspase still induces cell death. Thus, inhibition of TAK1 is one of the most promising approaches to therapeutic cell killing, as proposed also in recent cancer studies. ${ }^{102,105}$ This further emphasizes the importance of studies elucidating the regulatory mechanisms of TAK1 in the cell death network.

\section{Conflict of Interest}

The authors declare no conflict of interest.

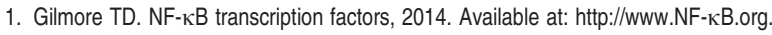

2. Pahl HL. Activators and target genes of Rel/NF- $\mathrm{KB}$ transcription factors. Oncogene 1999; 18: 6853-6866.

3. Hayden MS, Ghosh S. Shared principles in NF- $\kappa$ B signaling. Cell 2008; 132: 344-362.

4. Yamaguchi K, Shirakabe K, Shibuya H, Irie K, Oishi I, Ueno N et al. Identification of a member of the MAPKKK family as a potential mediator of TGF- $\beta$ signal transduction. Science 1995; 270: 2008-2011.

5. Ajibade AA, Wang HY, Wang RF. Cell type-specific function of TAK1 in innate immune signaling. Trends Immunol 2013; 34: 307-316. 
6. Ninomiya-Tsuji J, Kishimoto K, Hiyama A, Inoue J, Cao Z, Matsumoto K. The kinase TAK1 can activate the NIK-I $\kappa$ B as well as the MAP kinase cascade in the IL-1 signalling pathway. Nature 1999; 398: 252-256.

7. Sakurai $\mathrm{H}$. Targeting of TAK1 in inflammatory disorders and cancer. Trends Pharmacol Sci 2012; 33: 522-530.

8. Sato S, Sanjo H, Takeda K, Ninomiya-Tsuji J, Yamamoto M, Kawai T et al. Essential function for the kinase TAK1 in innate and adaptive immune responses. Nat Immunol 2005; 6: 1087-1095.

9. Tseng PH, Matsuzawa A, Zhang W, Mino T, Vignali DA, Karin M. Different modes of ubiquitination of the adaptor TRAF3 selectively activate the expression of type I interferons and proinflammatory cytokines. Nat Immunol 2010; 11: 70-75.

10. Sato S, Sanjo H, Tsujimura T, Ninomiya-Tsuji J, Yamamoto M, Kawai T et al. TAK1 is indispensable for development of $\mathrm{T}$ cells and prevention of colitis by the generation of regulatory T cells. Int Immunol 2006; 18: 1405-1411.

11. Wan $Y Y$, Chi H, Xie M, Schneider MD, Flavell RA. The kinase TAK1 integrates antigen and cytokine receptor signaling for T cell development, survival and function. Nat Immunol 2006; 7: 851-858.

12. Liu HH, Xie M, Schneider MD, Chen ZJ. Essential role of TAK1 in thymocyte development and activation. Proc Natl Acad Sci USA 2006; 103: 11677-11682.

13. Shirakabe K, Yamaguchi K, Shibuya H, Irie K, Matsuda S, Moriguchi T et al. TAK1 mediates the ceramide signaling to stress-activated protein kinase/c-Jun $\mathrm{N}$-terminal kinase. J Biol Chem 1997; 272: 8141-8144.

14. Herrero-Martin G, Hoyer-Hansen M, Garcia-Garcia C, Fumarola C, Farkas T, Lopez-Rivas A et al. TAK1 activates AMPK-dependent cytoprotective autophagy in TRAIL-treated epithelial cells. EMBO J 2009; 28: 677-685.

15. Morioka S, Omori E, Kajino T, Kajino-Sakamoto R, Matsumoto K, Ninomiya-Tsuji J. TAK1 kinase determines TRAIL sensitivity by modulating reactive oxygen species and CIAP. Oncogene 2009; 28: 2257-2265.

16. Inagaki M, Omori E, Kim JY, Komatsu Y, Scott G, Ray MK et al. TAK1-binding protein 1, TAB1, mediates osmotic stress-induced TAK1 activation but is dispensable for TAK1-mediated cytokine signaling. J Biol Chem 2008; 283: 33080-33086.

17. Xie M, Zhang D, Dyck JR, Li Y, Zhang H, Morishima M et al. A pivotal role for endogenous TGF- $\beta$-activated kinase- 1 in the LKB1/AMP-activated protein kinase energy-sensor pathway. Proc Natl Acad Sci USA 2006; 103: 17378-17383.

18. Ea CK, Deng L, Xia ZP, Pineda G, Chen ZJ. Activation of IKK by TNF $\alpha$ requires site-specific ubiquitination of RIP1 and polyubiquitin binding by NEMO. Mol Cell 2006; 22 : 245-257.

19. Mahoney DJ, Cheung HH, Mrad RL, Plenchette S, Simard C, Enwere E et al. Both clAP1 and clAP2 regulate TNF $\alpha$-mediated NF-kB activation. Proc Natl Acad Sci USA 2008; 105: 11778-11783.

20. Tokunaga F, Sakata S, Saeki Y, Satomi Y, Kirisako T, Kamei K et al. Involvement of linear polyubiquitylation of NEMO in NF-אB activation. Nat Cell Biol 2009; 11: 123-132.

21. Haas TL, Emmerich $\mathrm{CH}$, Gerlach B, Schmukle AC, Cordier SM, Rieser E et al. Recruitment of the linear ubiquitin chain assembly complex stabilizes the TNF-R1 signaling complex and is required for TNF-mediated gene induction. Mol Cell 2009; 36: 831-844.

22. Gerlach B, Cordier SM, Schmukle AC, Emmerich CH, Rieser E, Haas TL et al. Linear ubiquitination prevents inflammation and regulates immune signalling. Nature 2011; 471: 591-596.

23. Kishida S, Sanjo H, Akira S, Matsumoto K, Ninomiya-Tsuji J. TAK1-binding protein 2 facilitates ubiquitination of TRAF6 and assembly of TRAF6 with IKK in the IL-1 signaling pathway. Genes Cells 2005; 10: 447-454.

24. Kanayama A, Seth RB, Sun L, Ea CK, Hong M, Shaito A et al. TAB2 and TAB3 activate the NF-KB pathway through binding to polyubiquitin chains. Mol Cell 2004; 15: $535-548$.

25. Shim JH, Xiao C, Paschal AE, Bailey ST, Rao P, Hayden MS et al. TAK1, but not TAB1 or TAB2, plays an essential role in multiple signaling pathways in vivo. Genes Dev 2005; 19 : 2668-2681.

26. Chang L, Kamata H, Solinas G, Luo JL, Maeda S, Venuprasad K et al. The E3 ubiquitin ligase itch couples JNK activation to TNF $\alpha$-induced cell death by inducing $c-F L I P(L)$ turnover. Cell 2006; 124: 601-613.

27. Wang CY, Mayo MW, Korneluk RG, Goeddel DV, Baldwin AS Jr. NF- $\kappa B$ antiapoptosis: induction of TRAF1 and TRAF2 and c-IAP1 and C-IAP2 to suppress caspase-8 activation. Science 1998; 281: 1680-1683.

28. Momcilovic M, Hong SP, Carlson M. Mammalian TAK1 activates Snf1 protein kinase in yeast and phosphorylates AMP-activated protein kinase in vitro. J Biol Chem 2006; 281 : 25336-25343.

29. Criollo A, Niso-Santano M, Malik SA, Michaud M, Morselli E, Marino G et al. Inhibition of autophagy by TAB2 and TAB3. EMBO J 2011; 30: 4908-4920.

30. Shibuya H, Yamaguchi K, Shirakabe K, Tonegawa A, Gotoh Y, Ueno N et al. TAB1: an activator of the TAK1 MAPKKK in TGF- $\beta$ signal transduction. Science 1996; 272 : $1179-1182$.

31. Takaesu G, Kishida S, Hiyama A, Yamaguchi K, Shibuya H, Irie K et al. TAB2, a novel adaptor protein, mediates activation of TAK1 MAPKKK by linking TAK1 to TRAF6 in the IL-1 signal transduction pathway. Mol Cell 2000; 5: 649-658.

32. Ishitani T, Takaesu G, Ninomiya-Tsuji J, Shibuya H, Gaynor RB, Matsumoto K. Role of the TAB2-related protein TAB3 in IL-1 and TNF signaling. EMBO J 2003; 22: 6277-6288.
33. Scholz R, Sidler CL, Thali RF, Winssinger N, Cheung PC, Neumann D. Autoactivation of transforming growth factor $\beta$-activated kinase 1 is a sequential bimolecular process. J Biol Chem 2010; 285: 25753-25766.

34. Kishimoto K, Matsumoto K, Ninomiya-Tsuji J. TAK1 mitogen-activated protein kinase kinase kinase is activated by autophosphorylation within its activation loop. J Biol Chem 2000; 275: 7359-7364.

35. Pathak S, Borodkin VS, Albarbarawi O, Campbell DG, Ibrahim A, van Aalten DM. O-GIcNAcylation of TAB1 modulates TAK1-mediated cytokine release. EMBO J 2012; 31 1394-1404.

36. Ikeda Y, Morioka S, Matsumoto K, Ninomiya-Tsuji J. TAK1 binding protein 2 is essential for liver protection from stressors. PLoS One 2014; 9: e88037.

37. Morioka S, Inagaki M, Komatsu Y, Mishina $Y$, Matsumoto K, Ninomiya-Tsuji J. TAK1 kinase signaling regulates embryonic angiogenesis by modulating endothelial cell survival and migration. Blood 2012; 120: 3846-3857.

38. Broglie P, Matsumoto K, Akira S, Brautigan DL, Ninomiya-Tsuji J. Transforming growth factor $\beta$-activated kinase 1 (TAK1) kinase adaptor, TAK1-binding protein 2, plays dual roles in TAK1 signaling by recruiting both an activator and an inhibitor of TAK1 kinase in tumor necrosis factor signaling pathway. J Biol Chem 2010; 285: 2333-2339.

39. Kajino $\mathrm{T}$, Ren H, lemura S, Natsume T, Stefansson B, Brautigan DL et al. Protein phosphatase 6 down-regulates TAK1 kinase activation in the IL-1 signaling pathway. J Biol Chem 2006; 281: 39891-39896.

40. Kim SI, Kwak JH, Wang L, Choi ME. Protein phosphatase $2 \mathrm{~A}$ is a negative regulator of transforming growth factor- $\beta 1$-induced TAK1 activation in mesangial cells. J Biol Chem 2008; 283: 10753-10763.

41. Omori E, Inagaki M, Mishina Y, Matsumoto K, Ninomiya-Tsuji J. Epithelial transforming growth factor $\beta$-activated kinase 1 (TAK1) is activated through two independent mechanisms and regulates reactive oxygen species. Proc Natl Acad Sci USA 2012; 109: 3365-3370.

42. Mihaly SR, Morioka S, Ninomiya-Tsuji J, Takaesu G. Activated macrophage survival is coordinated by TAK1 binding proteins. PLoS One 2014; 9: e94982.

43. Micheau O, Tschopp J. Induction of TNF receptor I-mediated apoptosis via two sequential signaling complexes. Cell 2003; 114: 181-190.

44. Vandenabeele $P$, Declercq W, Van Herreweghe F, Vanden Berghe T. The role of the kinases RIP1 and RIP3 in TNF-induced necrosis. Sci Signal 2010; 3: re4.

45. Vandenabeele P, Galluzzi L, Vanden Berghe T, Kroemer G. Molecular mechanisms of necroptosis: an ordered cellular explosion. Nat Rev Mol Cell Biol 2010; 11: 700-714.

46. Kaczmarek A, Vandenabeele P, Krysko DV. Necroptosis: the release of damageassociated molecular patterns and its physiological relevance. Immunity 2013; 38: 209-223.

47. Degterev A, Hitomi J, Germscheid M, Ch'en IL, Korkina O, Teng X et al. Identification of RIP1 kinase as a specific cellular target of necrostatins. Nat Chem Biol 2008; 4: 313-321.

48. He S, Wang L, Miao L, Wang T, Du F, Zhao L et al. Receptor interacting protein kinase-3 determines cellular necrotic response to TNF- $\alpha$. Cell 2009; 137: 1100-1111.

49. Morioka S, Broglie P, Omori E, Ikeda Y, Takaesu G, Matsumoto K et al. TAK1 kinase switches cell fate from apoptosis to necrosis following TNF stimulation. J Cell Biol 2014; 204: 607-623.

50. Deveraux QL, Roy N, Stennicke HR, Van Arsdale T, Zhou Q, Srinivasula SM et al. IAPs block apoptotic events induced by caspase- 8 and cytochrome $c$ by direct inhibition of distinct caspases. EMBO J 1998; 17: 2215-2223.

51. Oberst A, Green DR. It cuts both ways: reconciling the dual roles of caspase 8 in cell death and survival. Nat Rev Mol Cell Biol 2011; 12: 757-763.

52. Irmler M, Thome M, Hahne M, Schneider P, Hofmann K, Steiner V et al. Inhibition of death receptor signals by cellular FLIP. Nature 1997; 388: 190-195.

53. Chang DW, Xing Z, Pan Y, Algeciras-Schimnich A, Barnhart BC, Yaish-Ohad S et al. c-FLIP $(L)$ is a dual function regulator for caspase-8 activation and CD95-mediated apoptosis. EMBO J 2002; 21: 3704-3714.

54. Oberst $A$, Dillon $C P$, Weinlich $R$, McCormick LL, Fitzgerald $P$, Pop $C$ et al. Catalytic activity of the caspase-8-FLIP(L) complex inhibits RIPK3-dependent necrosis. Nature 2011; 471: 363-367.

55. Kajino-Sakamoto R, Inagaki M, Lippert E, Akira S, Robine S, Matsumoto K et al. Enterocyte-derived TAK1 signaling prevents epithelium apoptosis and the development of ileitis and colitis. J Immunol 2008; 181: 1143-1152.

56. Nenci A, Becker C, Wullaert A, Gareus R, van Loo G, Danese S et al. Epithelial NEMO links innate immunity to chronic intestinal inflammation. Nature 2007; 446: 557-561.

57. Bettermann K, Vucur M, Haybaeck J, Koppe C, Janssen J, Heymann F et al. TAK1 suppresses a NEMO-dependent but NF- $\kappa$ B-independent pathway to liver cancer. Cancer Cell 2010; 17: 481-496.

58. Lamothe B, Lai Y, Xie M, Schneider MD, Darnay BG. TAK1 is essential for osteoclast differentiation and is an important modulator of cell death by apoptosis and necroptosis. Mol Cell Biol 2013; 33: 582-595.

59. Arslan SC, Scheidereit $C$. The prevalence of TNF $\alpha$-induced necrosis over apoptosis is determined by TAK1-RIP1 interplay. PLoS One 2011; 6: e26069.

60. Ting AT, Pimentel-Muinos FX, Seed B. RIP mediates tumor necrosis factor receptor 1 activation of NF- $\mathrm{KB}$ but not Fas/APO-1-initiated apoptosis. EMBO J 1996; 15 6189-6196

61. Ofengeim D, Yuan J. Regulation of RIP1 kinase signalling at the crossroads of inflammation and cell death. Nat Rev Mol Cell Biol 2013; 14: 727-736. 
62. Wang L, Du F, Wang X. TNF- $\alpha$ induces two distinct caspase- 8 activation pathways. Cell 2008; 133: 693-703.

63. Tenev T, Bianchi K, Darding M, Broemer M, Langlais C, Wallberg F et al. The Ripoptosome, a signaling platform that assembles in response to genotoxic stress and loss of IAPs. Mol Cell 2011; 43: 432-448.

64. Bertrand MJ, Milutinovic S, Dickson KM, Ho WC, Boudreault A, Durkin J et al. clAP1 and cIAP2 facilitate cancer cell survival by functioning as E3 ligases that promote RIP1 ubiquitination. Mol Cell 2008; 30: 689-700.

65. Kajino-Sakamoto R, Omori E, Nighot PK, Blikslager AT, Matsumoto K, Ninomiya-Tsuji J. TGF- $\beta$-activated kinase 1 signaling maintains intestinal integrity by preventing accumulation of reactive oxygen species in the intestinal epithelium. J Immunol 2010; 185: 4729-4737.

66. Omori E, Morioka S, Matsumoto K, Ninomiya-Tsuji J. TAK1 regulates reactive oxygen species and cell death in keratinocytes, which is essential for skin integrity. $J$ Biol Chem 2008; 283: 26161-26168.

67. Wang H, Sun L, Su L, Rizo J, Liu L, Wang LF et al. Mixed lineage kinase domain-like protein MLKL causes necrotic membrane disruption upon phosphorylation by RIP3. Mol Cell 2014; 54: 133-146.

68. Cai Z, Jitkaew S, Zhao J, Chiang HC, Choksi S, Liu J et al. Plasma membrane translocation of trimerized MLKL protein is required for TNF-induced necroptosis. Nat Cell Biol 2014; 16: 55-65.

69. Sun L, Wang H, Wang Z, He S, Chen S, Liao D et al. Mixed lineage kinase domain-like protein mediates necrosis signaling downstream of RIP3 kinase. Cell 2012; 148 213-227

70. Wang $Z$, Jiang $H$, Chen S, Du F, Wang $X$. The mitochondrial phosphatase PGAM5 functions at the convergence point of multiple necrotic death pathways. Cell 2012; 148: 228-243.

71. Remijsen Q, Goossens V, Grootjans S, Van den Haute C, Vanlangenakker N, Dondelinger $Y$ et al. Depletion of RIPK3 or MLKL blocks TNF-driven necroptosis and switches towards a delayed RIPK1 kinase-dependent apoptosis. Cell Death Dis 2014; 5 e1004.

72. Murphy JM, Czabotar PE, Hildebrand JM, Lucet IS, Zhang JG, Alvarez-Diaz S et al. The pseudokinase MLKL mediates necroptosis via a molecular switch mechanism. Immunity 2013; 39: 443-453.

73. Cho YS, Challa S, Moquin D, Genga R, Ray TD, Guildford M et al. Phosphorylation-driven assembly of the RIP1-RIP3 complex regulates programmed necrosis and virus-induced inflammation. Cell 2009; 137: 1112-1123.

74. He S, Wang L, Miao L, Wang T, Du F, Zhao L et al. Receptor interacting protein kinase-3 determines cellular necrotic response to TNF- $\alpha$. Cell 2009; 137: 1100-1111.

75. Zhang DW, Shao J, Lin J, Zhang N, Lu BJ, Lin SC et al. RIP3, an energy metabolism regulator that switches TNF-induced cell death from apoptosis to necrosis. Science 2009; 325: 332-336.

76. O'Donnell MA, Perez-Jimenez E, Oberst A, $\mathrm{Ng} \mathrm{A}$, Massoumi R, Xavier R et al. Caspase 8 inhibits programmed necrosis by processing CYLD. Nat Cell Biol 2011; 13 1437-1442.

77. Arslan SC, Scheidereit $\mathrm{C}$. The prevalence of TNF $\alpha$-induced necrosis over apoptosis is determined by TAK1-RIP1 interplay. PLoS One 2011; 6: e26069.

78. Vanlangenakker N, Vanden Berghe T, Bogaert P, Laukens B, Zobel K, Deshayes K et al. CIAP1 and TAK1 protect cells from TNF-induced necrosis by preventing RIP1/RIP3 dependent reactive oxygen species production. Cell Death Differ 2011; 18: 656-665.

79. Dondelinger Y, Aguileta MA, Goossens V, Dubuisson C, Grootjans S, Dejardin E et al. RIPK3 contributes to TNFR1-mediated RIPK1 kinase-dependent apoptosis in conditions of CIAP1/2 depletion or TAK1 kinase inhibition. Cell Death Differ 2013; 20 : 1381-1392.

80. Dillon CP, Weinlich R, Rodriguez DA, Cripps JG, Quarato G, Gurung $P$ et al. RIPK1 blocks early postnatal lethality mediated by caspase-8 and RIPK3. Cell 2014; 157 1189-1202.

81. Rickard JA, O'Donnell JA, Evans JM, Lalaoui N, Poh AR, Rogers T et al. RIPK1 regulates RIPK3-MLKL-driven systemic inflammation and emergency hematopoiesis. Cell 2014 157: $1175-1188$.

82. Omori E, Matsumoto K, Sanjo H, Sato S, Akira S, Smart RC et al. TAK1 is a master regulator of epidermal homeostasis involving skin inflammation and apoptosis. $J$ Bio Chem 2006; 281: 19610-19617.

83. Inokuchi S, Aoyama T, Miura K, Osterreicher CH, Kodama Y, Miyai K et al. Disruption of TAK1 in hepatocytes causes hepatic injury, inflammation, fibrosis, and carcinogenesis. Proc Natl Acad Sci USA 2010; 107: 844-849.

84. Takaesu G, Inagaki M, Takubo K, Mishina Y, Hess PR, Dean GA et al. TAK1 (MAP3K7) signaling regulates hematopoietic stem cells through TNF-dependent and -independen mechanisms. PLoS One 2012; 7: e51073.

85. Xiao Y, Li H, Zhang J, Volk A, Zhang S, Wei W et al. TNF- $\alpha /$ Fas-RIP-1-induced cell death signaling separates murine hematopoietic stem cells/progenitors into 2 distinct populations. Blood 2011; 118: 6057-6067.

86. Tang $M$, Wei $X$, Guo Y, Breslin $P$, Zhang $S$, Zhang $S$ et al. TAK1 is required for the survival of hematopoietic cells and hepatocytes in mice. J Exp Med 2008; 205: 1611-1619.

87. Ajibade AA, Wang $Q$, Cui J, Zou J, Xia X, Wang $M$ et al. TAK1 negatively regulates NF-кB and p38 MAP kinase activation in Gr-1 + CD11b + neutrophils. Immunity 2012 36: $43-54$.
88. Vucur M, Reisinger F, Gautheron J, Janssen J, Roderburg C, Cardenas DV et al. RIP3 inhibits inflammatory hepatocarcinogenesis but promotes cholestasis by controlling caspase-8- and JNK-dependent compensatory cell proliferation. Cell Rep 2013; 4: $776-790$

89. Lamothe B, Lai Y, Hur L, Orozco NM, Wang J, Campos AD et al. Deletion of TAK1 in the myeloid lineage results in the spontaneous development of myelomonocytic leukemia in mice. PLoS One 2012; 7: e51228.

90. Duprez L, Takahashi N, Van Hauwermeiren F, Vandendriessche B, Goossens V, Vanden Berghe $\mathrm{T}$ et al. RIP kinase-dependent necrosis drives lethal systemic inflammatory response syndrome. Immunity 2011; 35: 908-918.

91. Degterev A, Huang Z, Boyce M, Li Y, Jagtap P, Mizushima N et al. Chemical inhibitor of nonapoptotic cell death with therapeutic potential for ischemic brain injury. Nat Chem Biol 2005; 1: 112-119.

92. Kovalenko A, Kim JC, Kang TB, Rajput A, Bogdanov K, Dittrich-Breiholz $\mathrm{O}$ et al. Caspase-8 deficiency in epidermal keratinocytes triggers an inflammatory skin disease. J Exp Med 2009; 206: 2161-2177.

93. Gunther C, Martini E, Wittkopf N, Amann K, Weigmann B, Neumann H et al. Caspase-8 regulates TNF- $\alpha$-induced epithelial necroptosis and terminal ileitis. Nature 2011; 477 : 335-339.

94. Bonnet MC, Preukschat D, Welz PS, van Loo G, Ermolaeva MA, Bloch W et al. The adaptor protein FADD protects epidermal keratinocytes from necroptosis in vivo and prevents skin inflammation. Immunity 2011; 35: 572-582.

95. Welz PS, Wullaert A, Vlantis K, Kondylis V, Fernandez-Majada V, Ermolaeva M et al. FADD prevents RIP3-mediated epithelial cell necrosis and chronic intestinal inflammation. Nature 2011; 477: 330-334.

96. Kaiser WJ, Upton JW, Long AB, Livingston-Rosanoff D, Daley-Bauer LP, Hakem R et al. RIP3 mediates the embryonic lethality of caspase-8-deficient mice. Nature 2011; 471 : 368-372.

97. Newton K, Dugger DL, Wickliffe KE, Kapoor N, de Almagro MC, Vucic D et al. Activity of protein kinase RIPK3 determines whether cells die by necroptosis or apoptosis. Science 2014; 343: 1357-1360.

98. Dillon CP, Oberst A, Weinlich R, Janke LJ, Kang TB, Ben-Moshe T et al. Survival function of the FADD-CASPASE-8-CFLIP(L) complex. Cell Rep 2012; 1: 401-407.

99. Green DR, Oberst A, Dillon CP, Weinlich R, Salvesen GS. RIPK-dependent necrosis and its regulation by caspases: a mystery in five acts. Mol Cell 2011; 44: 9-16.

100. Lin Y, Devin A, Rodriguez Y, Liu ZG. Cleavage of the death domain kinase RIP by caspase-8 prompts TNF-induced apoptosis. Genes Dev 1999; 13: 2514-2526.

101. Feng S, Yang Y, Mei Y, Ma L, Zhu DE, Hoti N et al. Cleavage of RIP3 inactivates its caspase-independent apoptosis pathway by removal of kinase domain. Cell Signal 2007; 19: 2056-2067.

102. Ninomiya-Tsuji J, Kajino T, Ono K, Ohtomo T, Matsumoto M, Shiina M et al. A resorcylic acid lactone, 5Z-7-oxozeaenol, prevents inflammation by inhibiting the catalytic activity of TAK1 MAPK kinase kinase. J Biol Chem 2003; 278: 18485-18490.

103. Singh A, Sweeney MF, Yu M, Burger A, Greninger $P$, Benes $C$ et al. TAK1 inhibition promotes apoptosis in KRAS-dependent colon cancers. Cell 2012; 148: $639-650$.

104. Omori E, Matsumoto K, Zhu S, Smart RC, Ninomiya-Tsuji J. Ablation of TAK1 upregulates reactive oxygen species and selectively kills tumor cells. Cancer Res 2010; 70: 8417-8425.

105. Newton K, Sun X, Dixit VM. Kinase RIP3 is dispensable for normal NF- $\kappa$ Bs, signaling by the B-cell and T-cell receptors, tumor necrosis factor receptor 1, and Toll-like receptors 2 and 4. Mol Cell Biol 2004; 24: 1464-1469.

106. Tanaka M, Fuentes ME, Yamaguchi K, Durnin MH, Dalrymple SA, Hardy KL et al. Embryonic lethality, liver degeneration, and impaired NF-KB activation in IKK- $\beta$-deficient mice. Immunity 1999; 10: 421-429.

107. Li ZW, Chu W, Hu Y, Delhase M, Deerinck T, Ellisman M et al. The IKK $\beta$ subunit of $I_{\kappa} B$ kinase $(\mathrm{IKK})$ is essential for nuclear factor $\kappa \mathrm{B}$ activation and prevention of apoptosis. J Exp Med 1999; 189: 1839-1845.

108. Li Q, Van Antwerp D, Mercurio F, Lee KF, Verma IM. Severe liver degeneration in mice lacking the IкB kinase 2 gene. Science 1999; 284: 321-325.

109. Pasparakis M, Courtois G, Hafner M, Schmidt-Supprian M, Nenci A, Toksoy A et al. TNF-mediated inflammatory skin disease in mice with epidermis-specific deletion of IKK2. Nature 2002; 417: 861-866.

110. Egan LJ, Eckmann L, Greten FR, Chae S, Li ZW, Myhre GM et al. I KB-kinase $\beta$ dependent NF- $\mathrm{KB}$ activation provides radioprotection to the intestinal epithelium. Proc Natl Acad Sci USA 2004; 101: 2452-2457.

111. Maeda S, Chang L, Li ZW, Luo JL, Leffert H, Karin M. IKK $\beta$ is required for prevention of apoptosis mediated by cell-bound but not by circulating TNF $\alpha$. Immunity 2003; 19: 725-737.

112. Senftleben U, Li ZW, Baud V, Karin M. IKK $\beta$ is essential for protecting T cells from TNF $\alpha$-induced apoptosis. Immunity 2001; 14: 217-230.

113. Park JM, Greten FR, Wong A, Westrick RJ, Arthur JS, Otsu K et al. Signaling pathways and genes that inhibit pathogen-induced macrophage apoptosis - CREB and NF- $\kappa \mathrm{B}$ as key regulators. Immunity 2005; 23: 319-329.

114. Schmidt-Supprian M, Bloch W, Courtois G, Addicks K, Israel A, Rajewsky K et al. NEMO/IKK $\gamma$-deficient mice model incontinentia pigmenti. Mol Cell 2000; 5: 981-992. 
115. Makris C, Godfrey VL, Krahn-Senftleben G, Takahashi T, Roberts JL, Schwarz T et al. Female mice heterozygous for IKK $\gamma / \mathrm{NEMO}$ deficiencies develop a dermatopathy similar to the human X-linked disorder incontinentia pigmenti. Mol Cell 2000; 5: 969-979.

116. Nenci A, Huth M, Funteh A, Schmidt-Supprian M, Bloch W, Metzger D et al. Skin lesion development in a mouse model of incontinentia pigmenti is triggered by NEMO deficiency in epidermal keratinocytes and requires TNF signaling. Hum Mol Genet 2006; 15: 531-542.

117. Gareus R, Kotsaki E, Xanthoulea S, van der Made I, Gijbels MJ, Kardakaris R et al. Endothelial cell-specific NF- $\kappa B$ inhibition protects mice from atherosclerosis. Cell Metab 2008; 8: 372-383.

118. Luedde T, Beraza N, Kotsikoris V, van Loo G, Nenci A, De Vos R et al. Deletion of NEMO/IKK $\gamma$ in liver parenchymal cells causes steatohepatitis and hepatocellular carcinoma. Cancer Cell 2007; 11: 119-132.

119. Jadrich JL, O'Connor MB, Coucouvanis E. The TGF $\beta$ activated kinase TAK1 regulates vascular development in vivo. Development 2006; 133: 1529-1541.

120. Inagaki M, Komatsu $Y$, Scott G, Yamada G, Ray M, Ninomiya-Tsuji J et al. Generation of a conditional mutant allele for Tab1 in mouse. Genesis 2008; 46 : 431-439.

121. Komatsu Y, Shibuya H, Takeda N, Ninomiya-Tsuji J, Yasui T, Miyado K et al. Targeted disruption of the Tab1 gene causes embryonic lethality and defects in cardiovascular and lung morphogenesis. Mech Dev 2002; 119: 239-249.

122. Sanjo H, Takeda K, Tsujimura T, Ninomiya-Tsuji J, Matsumoto K, Akira S. TAB2 is essential for prevention of apoptosis in fetal liver but not for interleukin-1 signaling. $\mathrm{Mol}$ Cell Biol 2003; 23: 1231-1238.

123. Ori D, Kato H, Sanjo H, Tartey S, Mino T, Akira S et al. Essential roles of K63-linked polyubiquitin-binding proteins TAB2 and TAB3 in B cell activation via MAPKs. J Immunol 2013; 190: 4037-4045.
124. Varfolomeev EE, Schuchmann M, Luria V, Chiannilkulchai N, Beckmann JS, Mett IL et al. Targeted disruption of the mouse caspase 8 gene ablates cell death induction by the TNF receptors, Fas/Apo1, and DR3 and is lethal prenatally. Immunity 1998; 9: 267-276.

125. Kang TB, Ben-Moshe T, Varfolomeev EE, Pewzner-Jung Y, Yogev N, Jurewicz A et al. Caspase-8 serves both apoptotic and nonapoptotic roles. J Immunol 2004; 173 2976-2984.

126. Zhang J, Cado D, Chen A, Kabra NH, Winoto A. Fas-mediated apoptosis and activationinduced T-cell proliferation are defective in mice lacking FADD/Mort1. Nature 1998; 392: 296-300.

127. Yeh WC, de la Pompa JL, McCurrach ME, Shu HB, Elia AJ, Shahinian A et al. FADD: essential for embryo development and signaling from some, but not all, inducers of apoptosis. Science 1998; 279: 1954-1958.

128. Yeh WC, Itie A, Elia AJ, Ng M, Shu HB, Wakeham A et al. Requirement for Casper (c-FLIP) in regulation of death receptor-induced apoptosis and embryonic development. Immunity 2000; 12: 633-642.

129. Panayotova-Dimitrova D, Feoktistova M, Ploesser M, Kellert B, Hupe M, Horn S et al. cFLIP regulates skin homeostasis and protects against TNF-induced keratinocyte apoptosis. Cell Rep 2013; 5: 397-408.

130. Wittkopf N, Gunther C, Martini E, He G, Amann K, He YW et al. Cellular FLICE-like inhibitory protein secures intestinal epithelial cell survival and immune homeostasis by regulating caspase-8. Gastroenterology 2013; 145: 1369-1379.

131. Schattenberg JM, Zimmermann T, Worns M, Sprinzl MF, Kreft A, Kohl T et al. Ablation of c-FLIP in hepatocytes enhances death-receptor mediated apoptosis and toxic liver injury in vivo. J Hepatol 2011; 55: 1272-1280.

132. Huang QQ, Perlman H, Huang Z, Birkett R, Kan L, Agrawal H et al. FLIP: a novel regulator of macrophage differentiation and granulocyte homeostasis. Blood 2010; 116: 4968-4977.

133. Kelliher MA, Grimm S, Ishida Y, Kuo F, Stanger BZ, Leder $P$. The death domain kinase RIP mediates the TNF-induced NF- $\kappa$ B signal. Immunity 1998; 8: 297-303. 